\title{
2019
}

\section{PANDUAN SINGKAT OJS 3.0 (REVIEWER)}

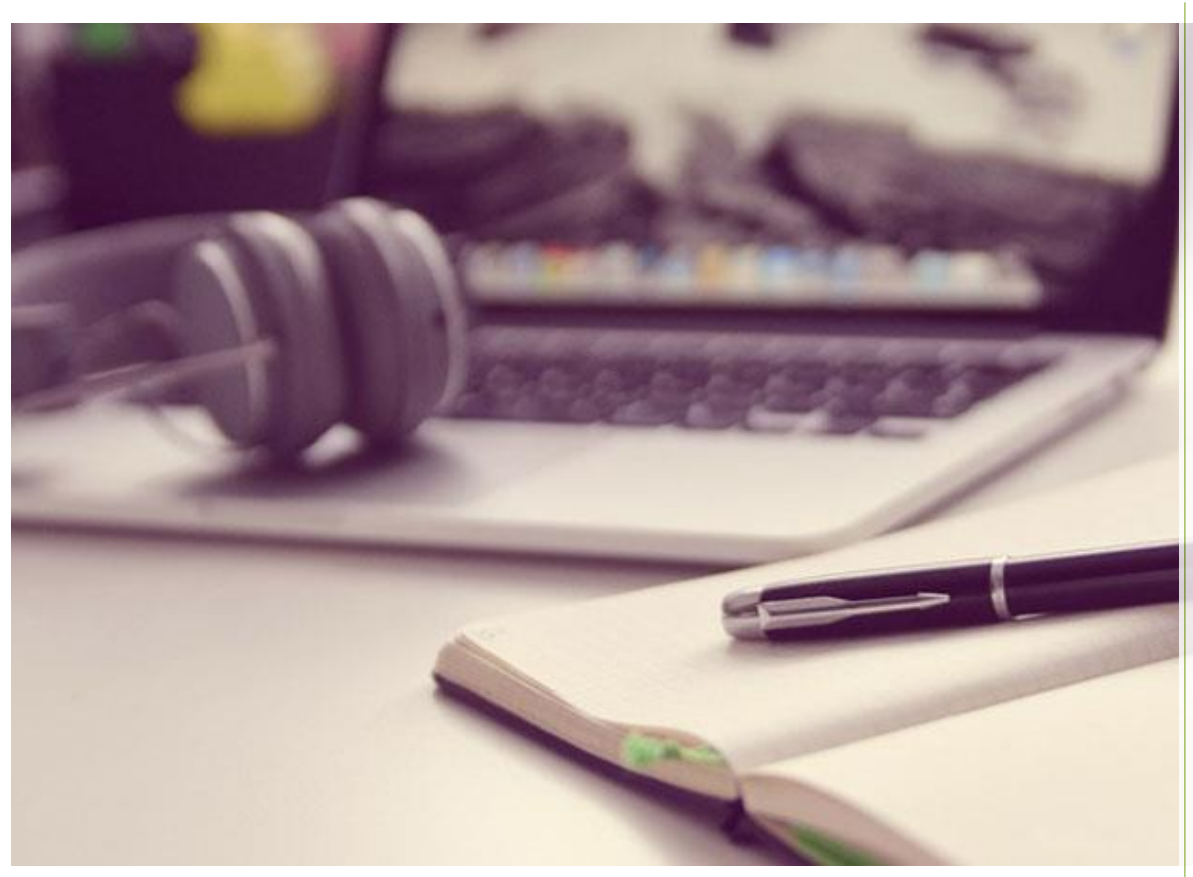

Hafiz Muchti Kurniawan

LPPM Universitas Adiwangsa Jambi 


\section{REGISTER DAN LOGIN}

Untuk mengakses jurnal elektronik/online yang menggunakan system OJS (Open Journal System) maka reviewer harus terdaftar dulu pada system ejournal Universitas Adiwangsa Jambi, proses registrasi bisa melalui dua cara :

1. User bisa mendaftar secara mandiri di system ejournal.unaja.ac.id

2. User bisa didaftarkan oleh pengelola jurnal (Journal Manager)

Proses "Register" dilakukan untuk pertama kali, jika Anda sama sekali belum pernah melakukan registrasi. Jika sudah pernah, cukup pilih "Login".

1. Akses OJS ejournal UNAJA di http://ejournal.unaja.ac.id/

2. Pilih Register

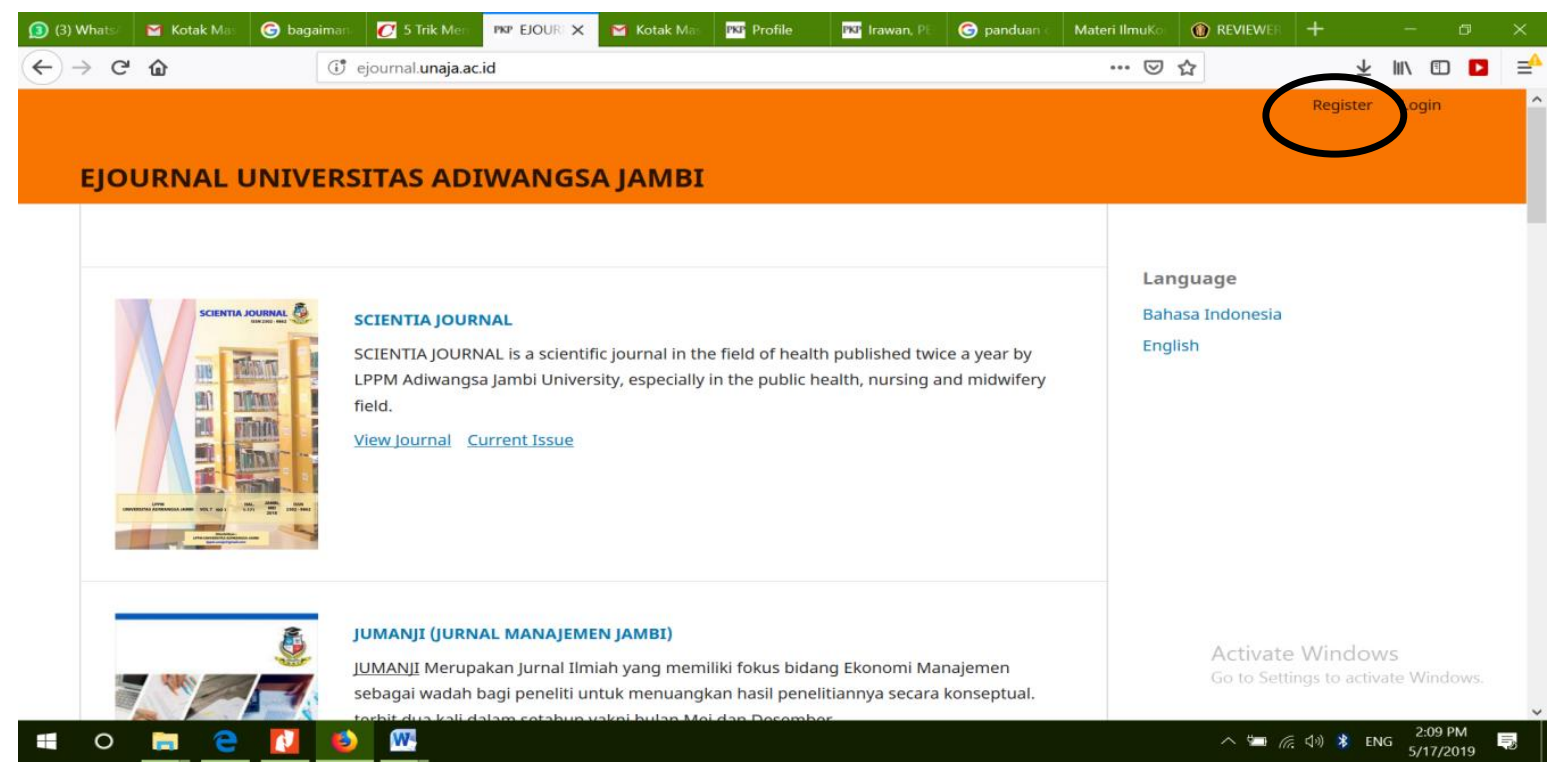

3. First Name (Nama pertama Anda)

4. Middle Name (Nama tengah Anda, jika ada)

5. Last Name (Nama akhir, jika ada,jika tidak ketikan juga "nama pertama" Anda di sini)

6. Affilliation (Ketikkan nama Program Studi \& Universitas

7. Country (pilih Indonesia)

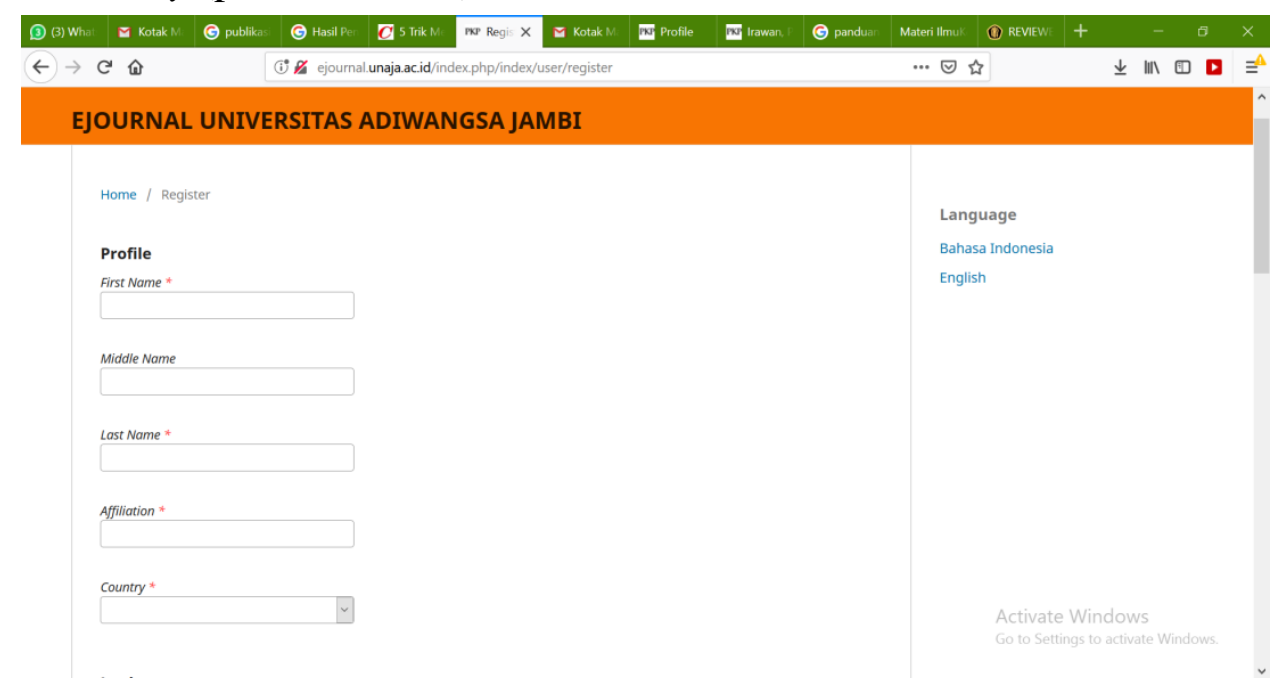


8. Email (email Anda yang valid)

9. Username (huruf kecil, tanpa spasi)

10. Password (ketikan password yang unik dan mudah diingat)

11. Repeat Password

12. Pilih "Reviewer" pada salah satu Jurnal yang diinginkan untuk di submit

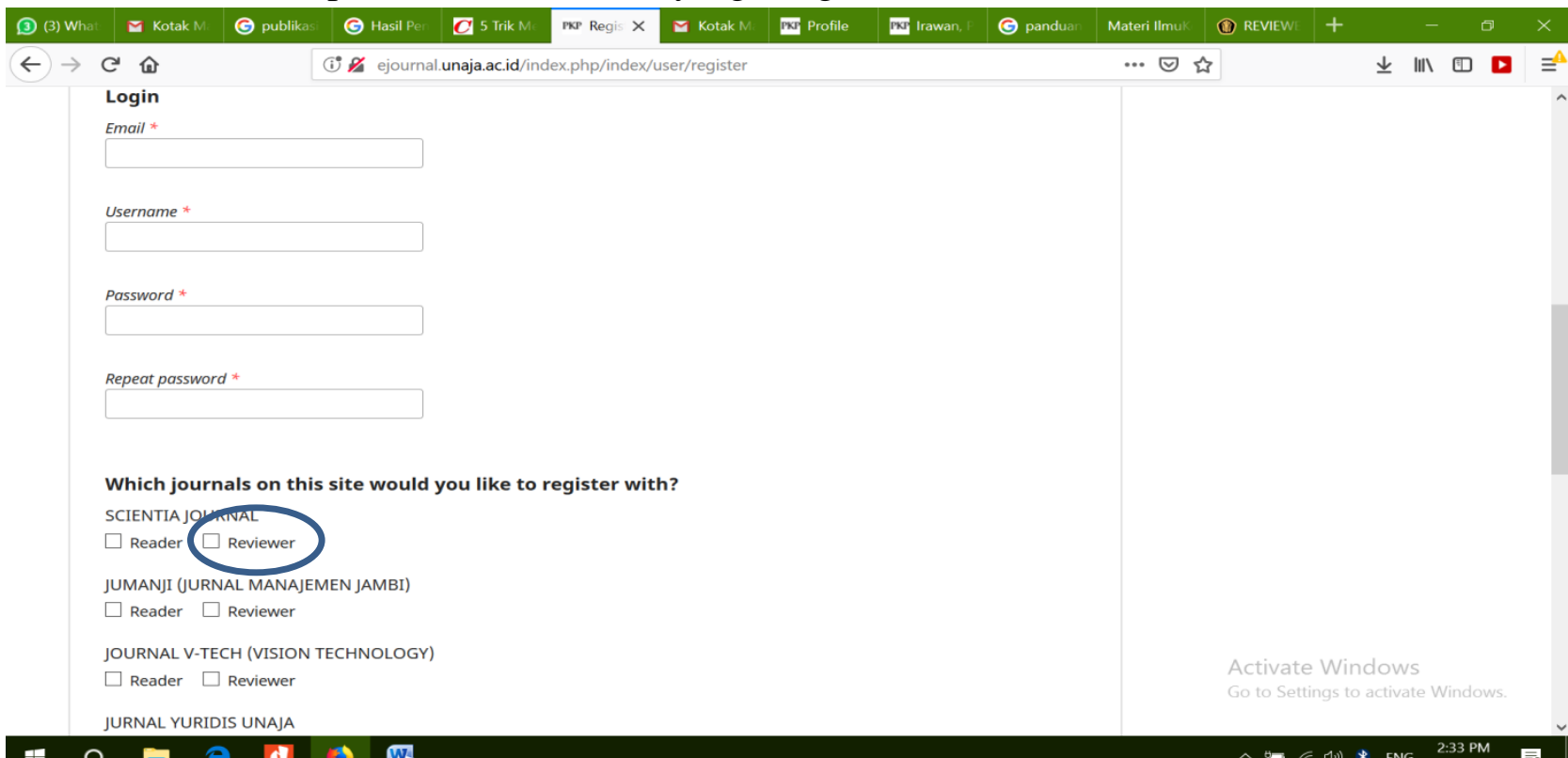

13. Klik "Register"

14. Kemudian Login dengan username dan Password yang telah dibuat

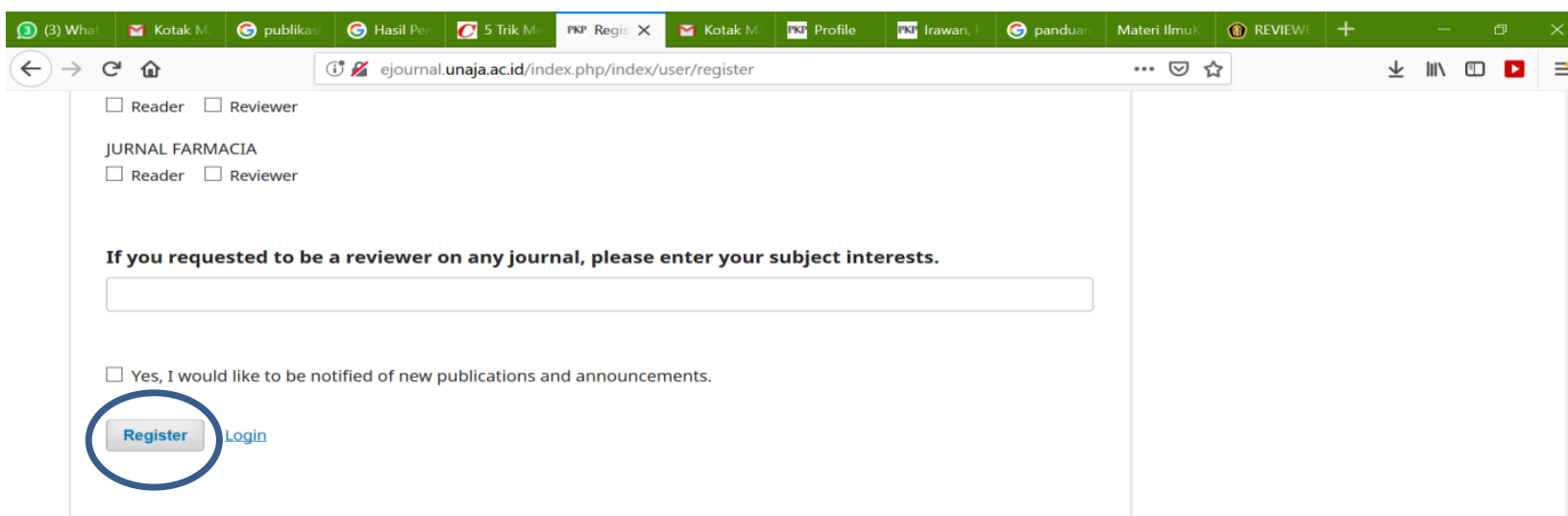

Platform \& workflow by

OJS / PKP
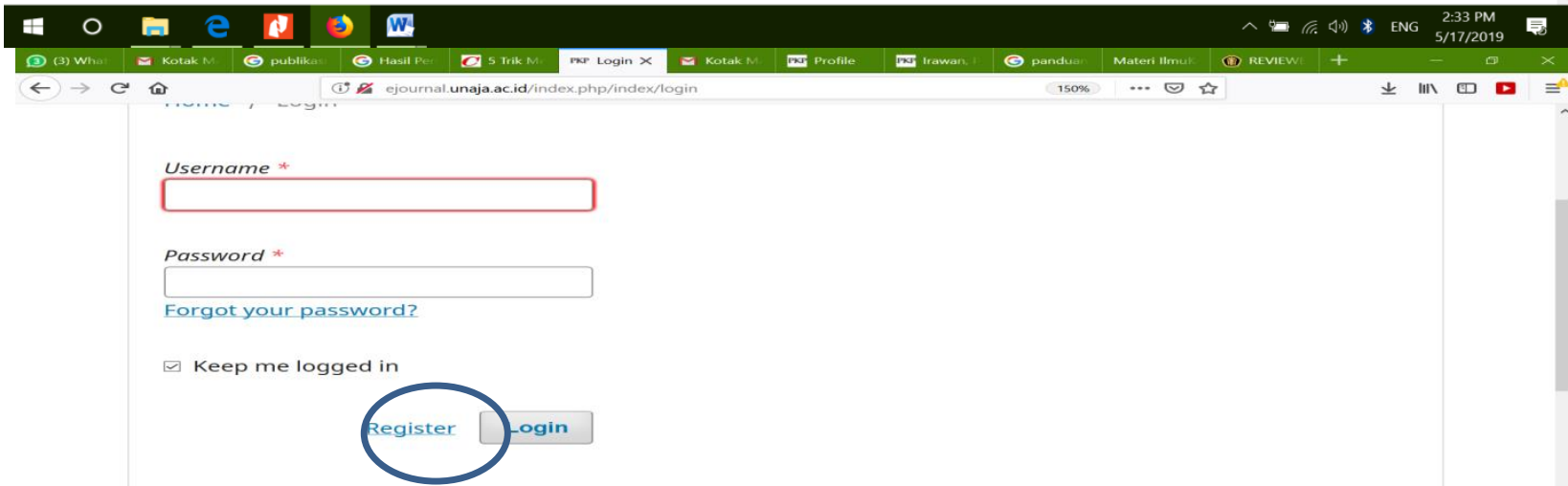


\section{PROSES REVIEW}

Langkah pertama adalah memulai proses review atau penilaian artikel :

D setelah login selesai kemudian pilih jurnal dimana user sebagai reviewer contoh : reviewer pada jurnal scientia journal

D pilih "Dashboard"

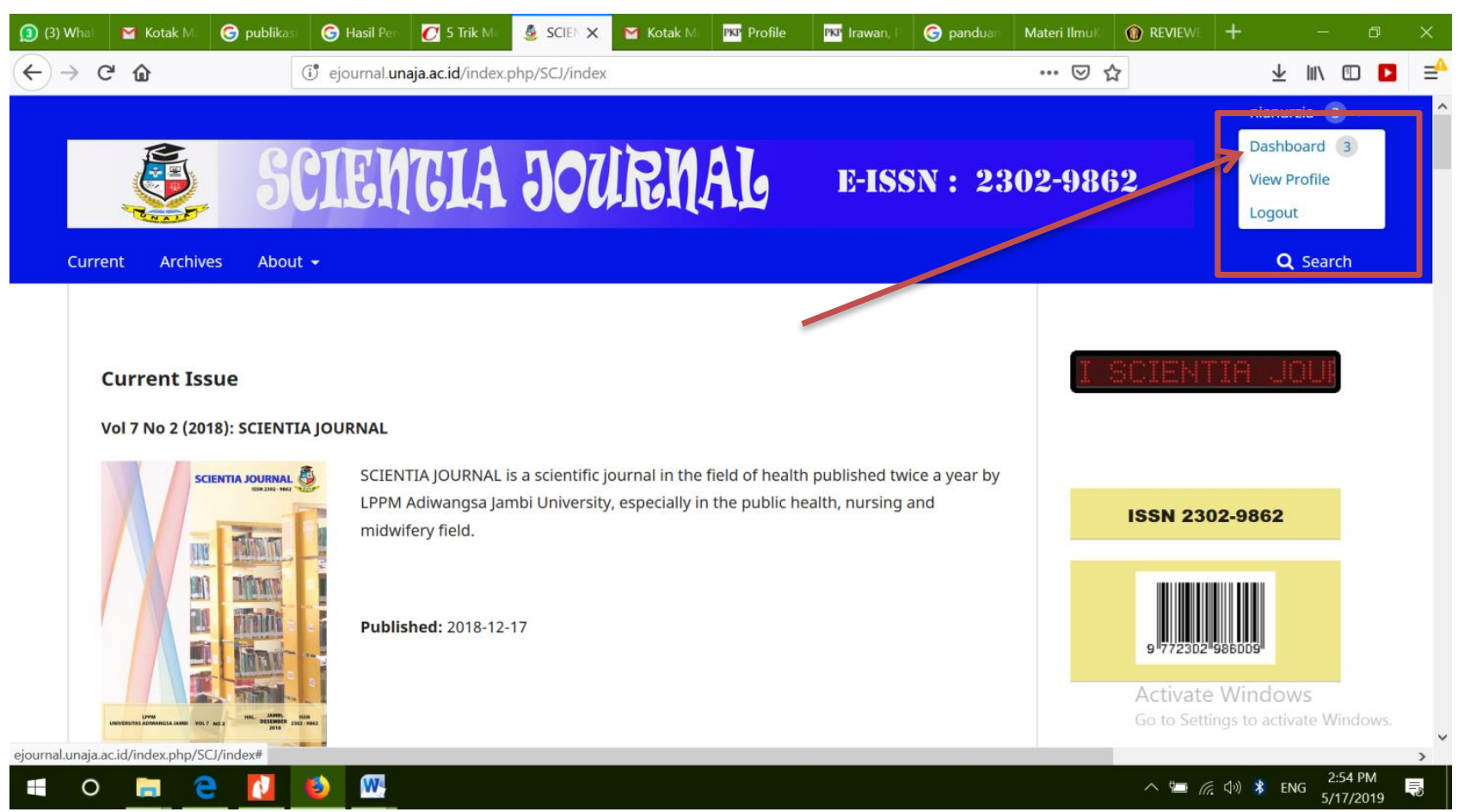

D kemudian akan masuk ke menu submission

D pilih salah satu artikel yang akan di review

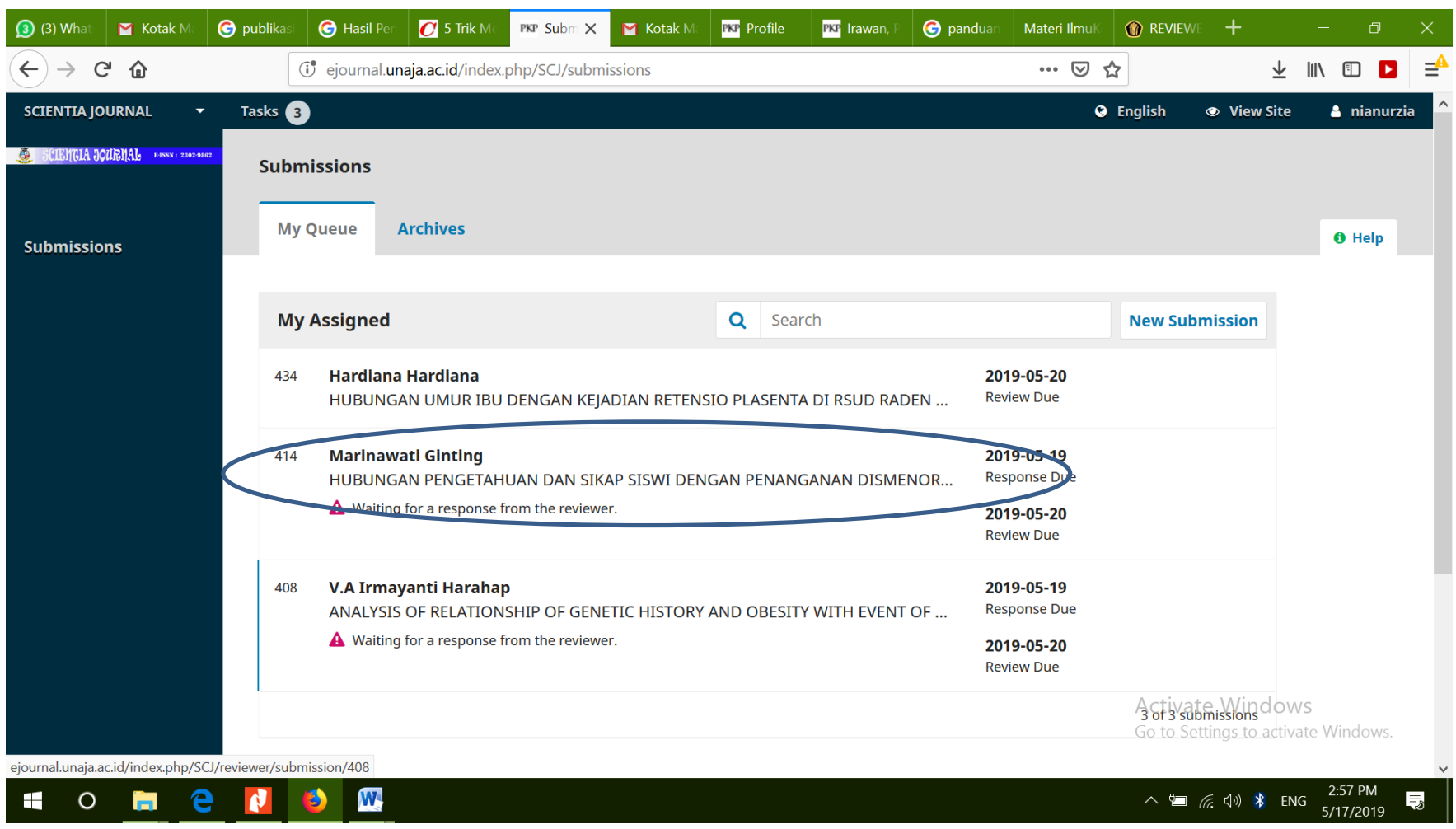


D kemudian akan masuk ke halaman "Request Review" (permintaan untuk menilai) berisi judul artikel dan abstrak, review files dan review schedule.

D review schedule berisi :

1. editor request (tanggal permintaan dari editor),

2. response due date (tanggal reviewer merespon penilaian),

3. review due date (batas waktu reviewer menilai artikel)

D apabila reviewer menyetujui/menyanggup untuk mereview artikel tersebut maka ceklist pernyataan "yes I agree..." dan klik accept review

D apabila reviewer menolak untuk mereview artikel tersebut maka pilih "decline review request"

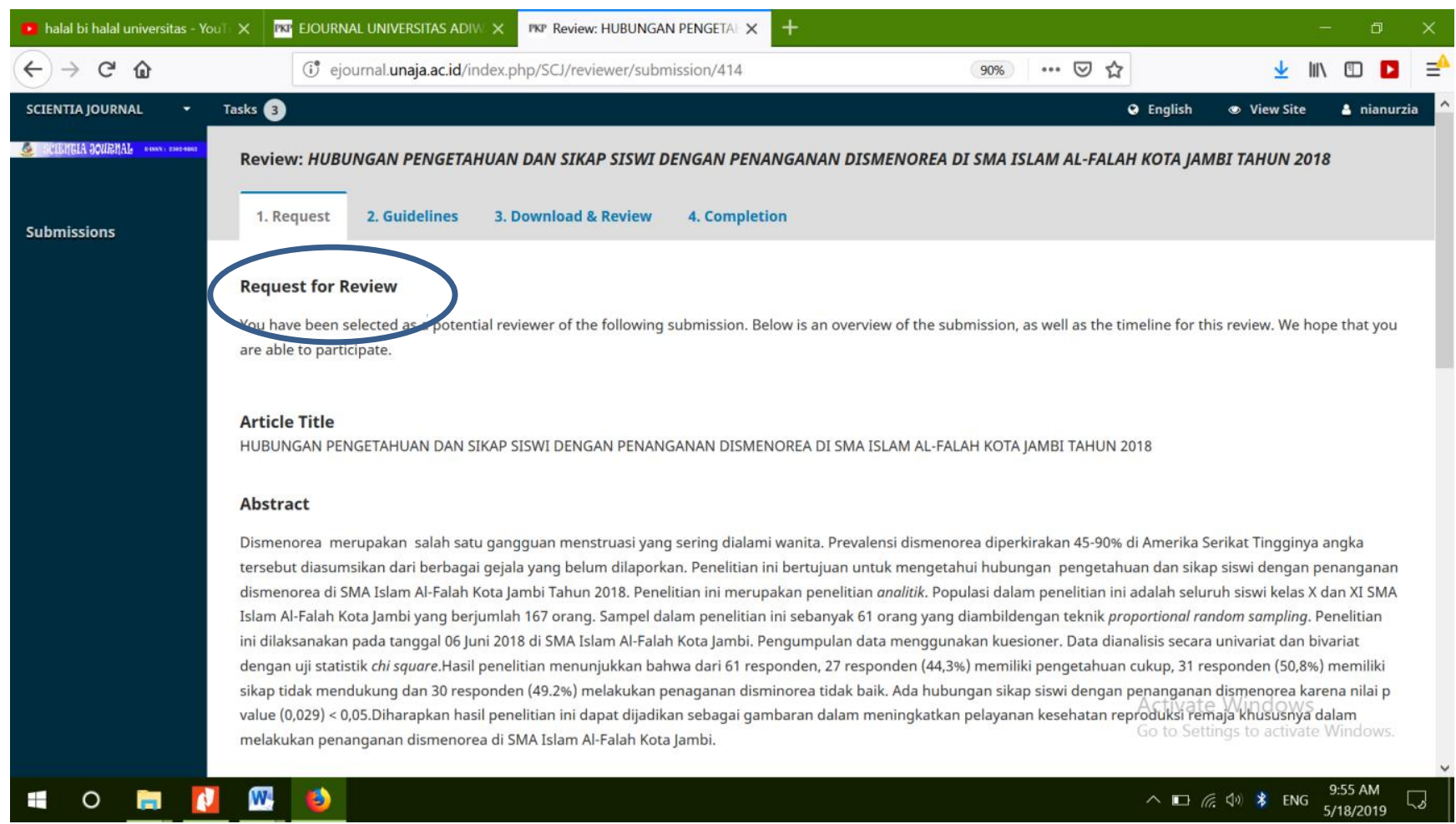

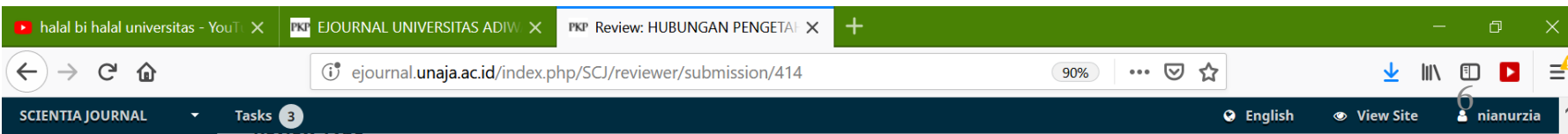

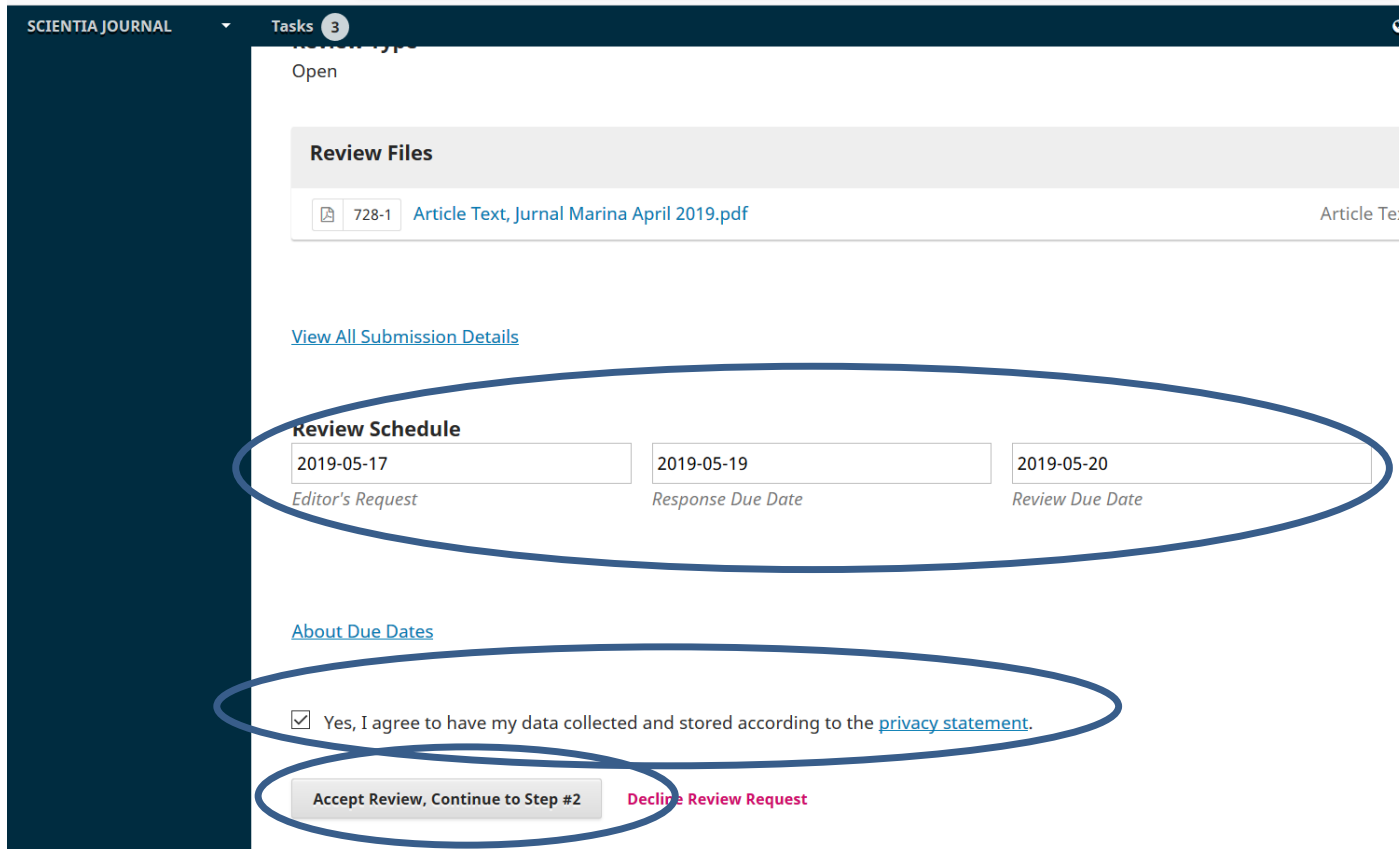


Langkah selanjutnya adalah akan masuk ke menu guidelines for reviewer, kemudian klik continue to step 3

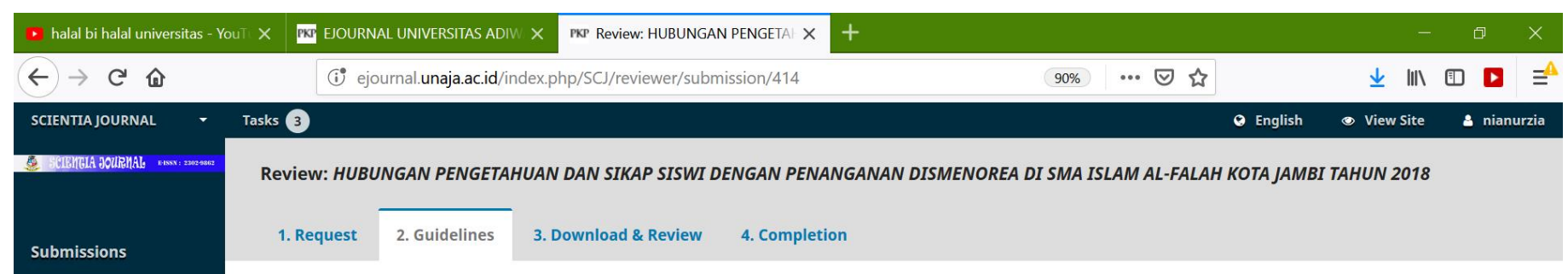

Reviewer Guidelines

This publisher has not set any reviewer guidelines.

Continue to Step \#3 Go Back

Selanjutnya akan masuk ke menu download dan review, di menu inilah reviewer akan diberikan Form review yang merupakan substansi penilaian suatu artikel yang akan dinilai, form review ini dinilai dengan menggunakan skor dari $1-4$.

Pada kolom review files reviewer dapat mendownload artikel text yang akan dinilai kemudian menilai dengan menggunakan MS.Word dengan menggunakan menu review di MS.Word

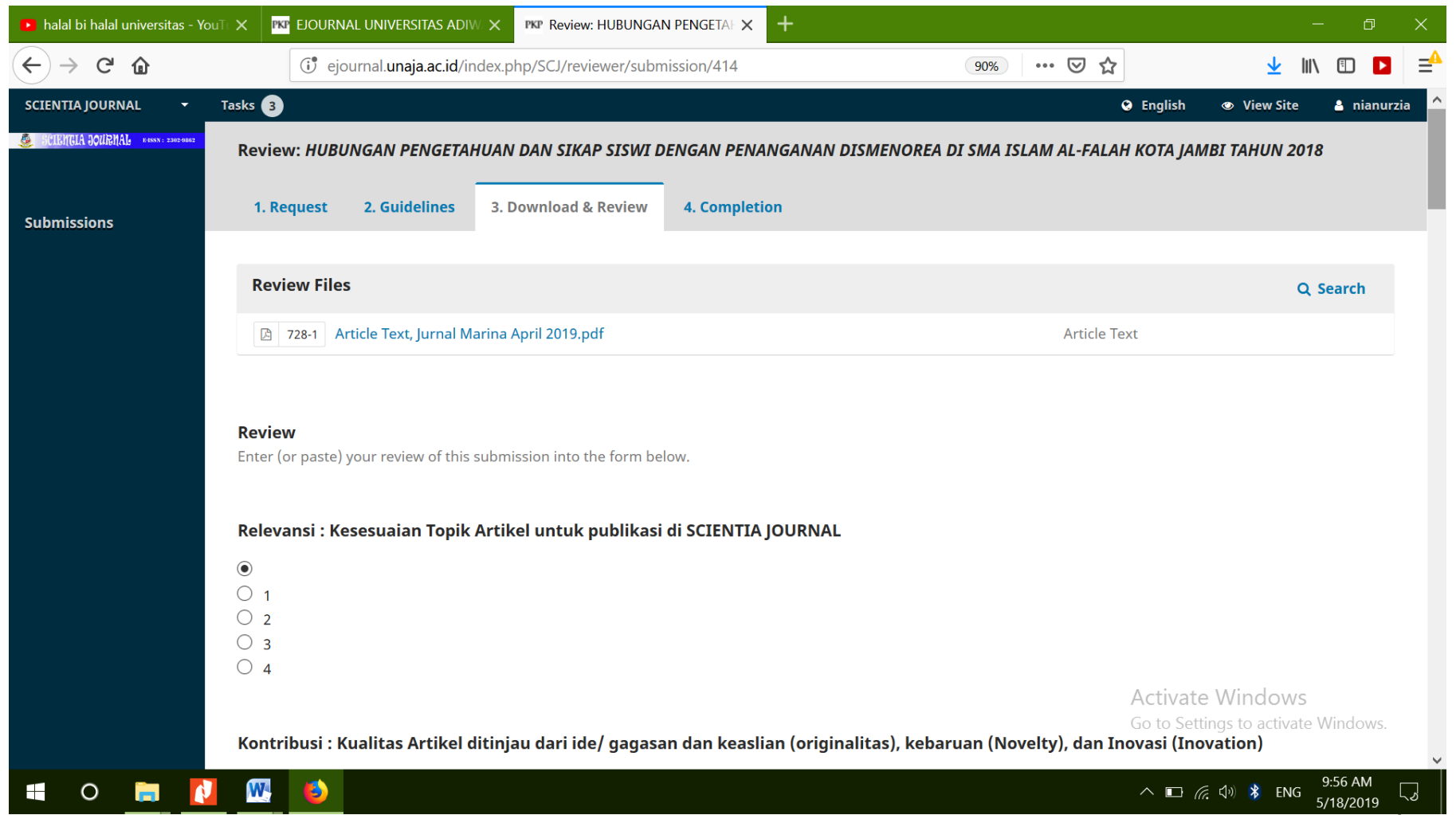


Proses penilaian dengan mengguanakan MS. Word dapat dilihat pada gambar dibawah ini :

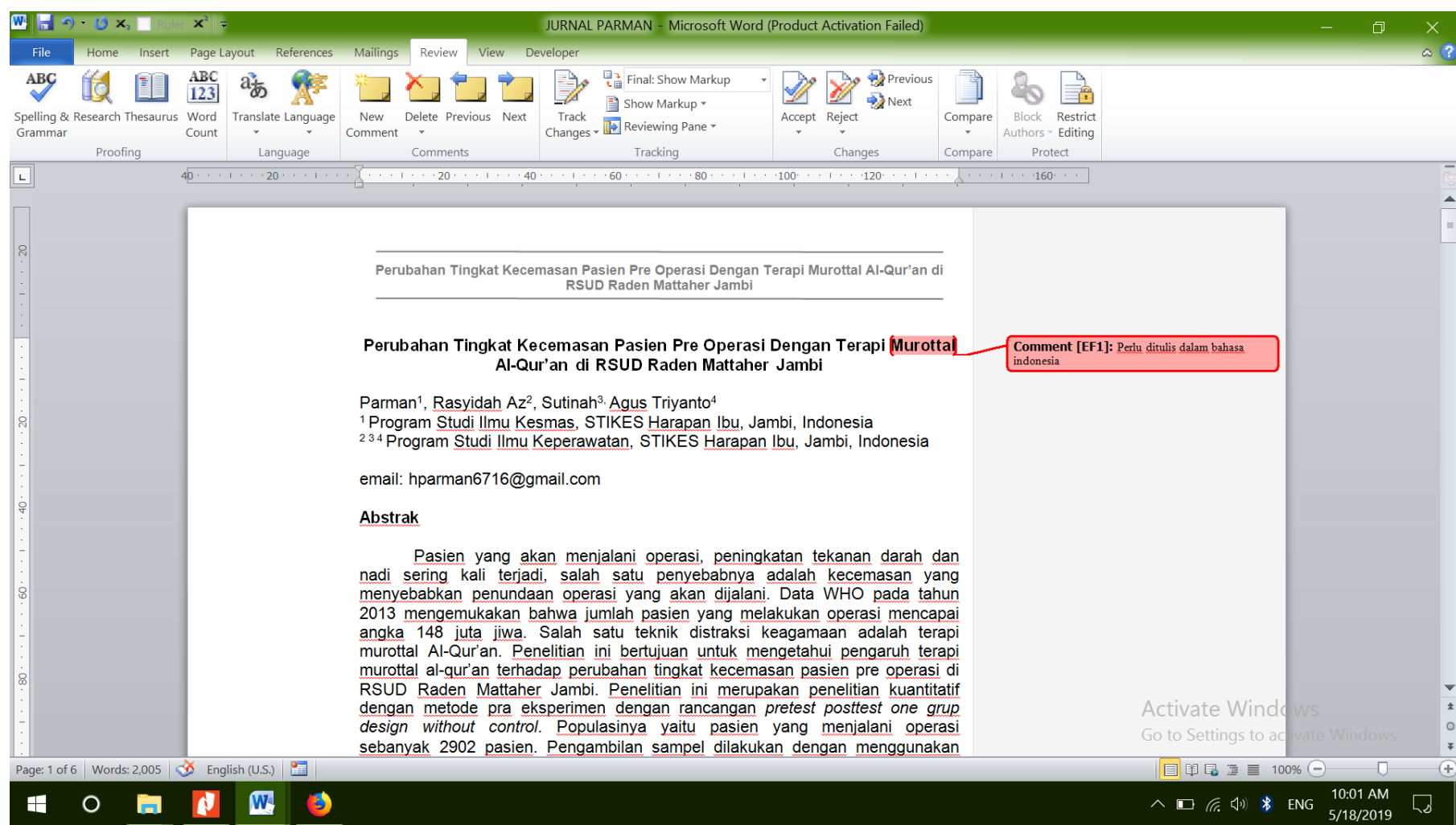

Setelah melakukan penilaian dan memberikan komentar terhadap artikel maka reviewer akan memberikan rekomendasi apakah suatu artikel tersebut :

1. diterima tanpa revisi

2. diterima dengan revisi minor

3. diterima dengan revisi mayor

4. ditolak

kemudian reviewer memberikan komentar di kolom "saran untuk author" dan "saran untuk editor"

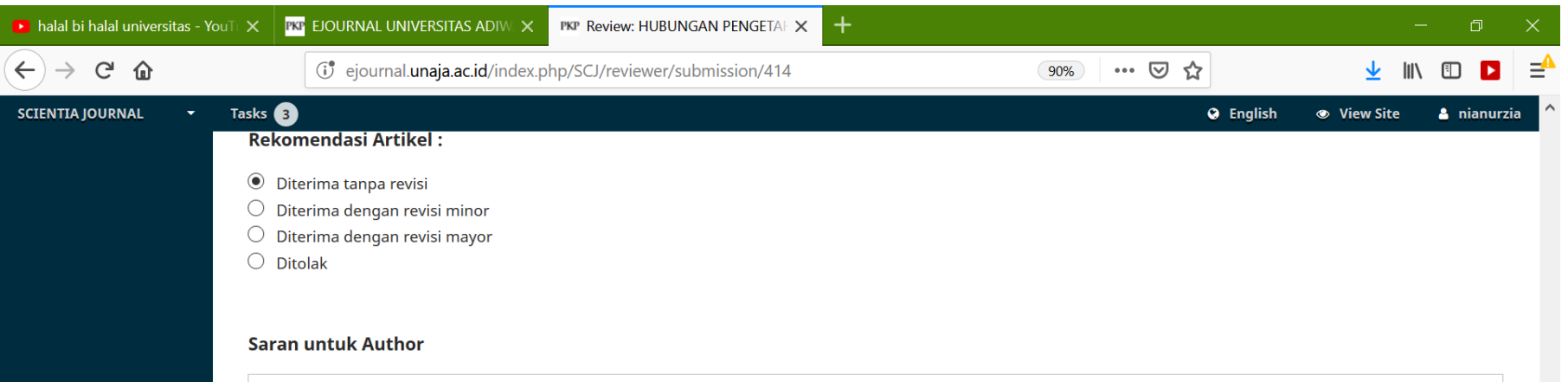

Saran Untuk Editor 
Setelah semua tahapan penilaian dilakukan ternyata artikel tersebut memerlukan revisi baik mayor ataupun minor maka reviewer bisa mengembalikan artikel tersebut kepada editor untuk selanjutnya dikembalikan ke author dengan menggunakan kolom upload.

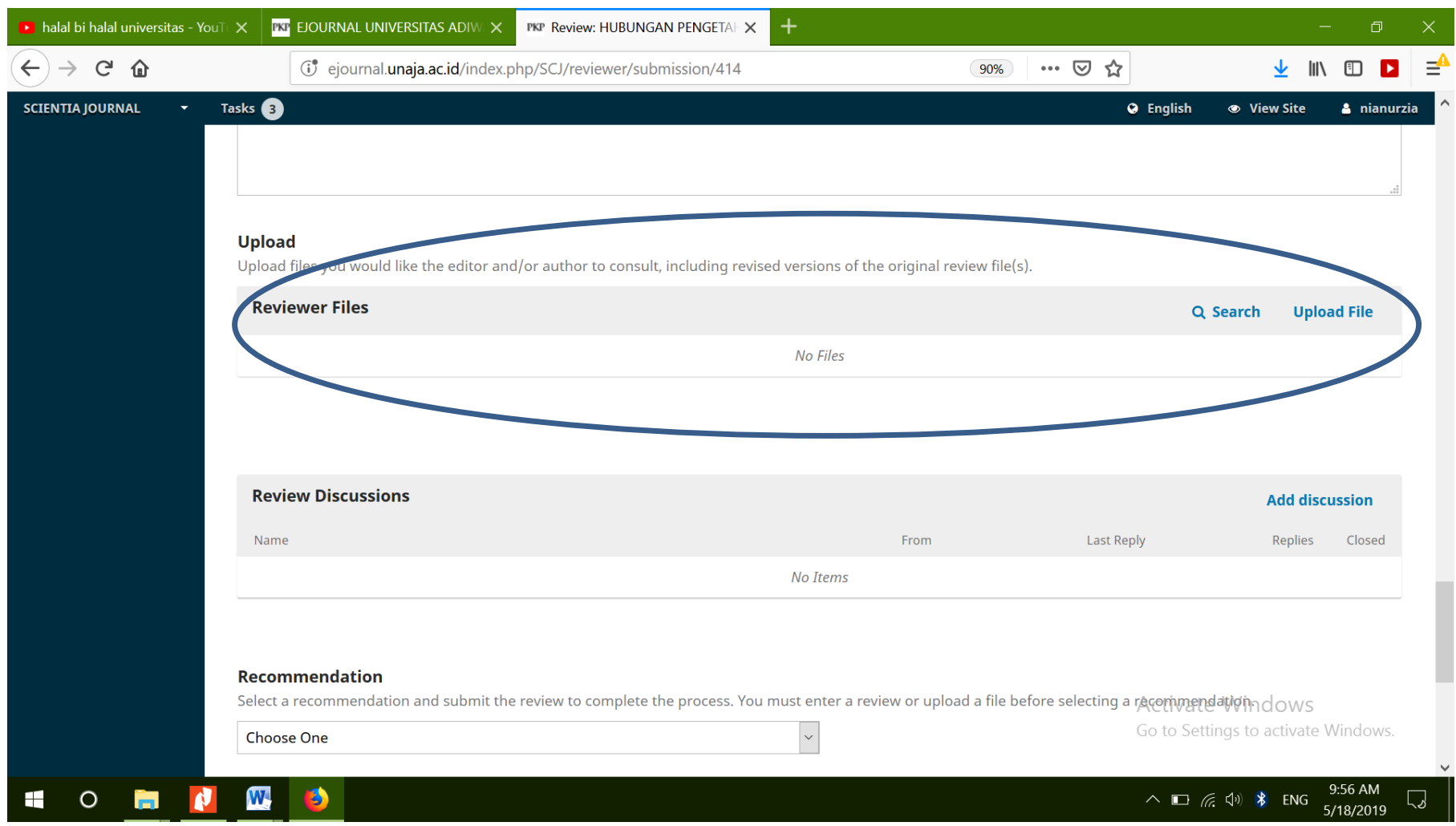

Jika semua proses review telah selesai maka reviewer mengirimkan artikel beserta rekomendasi dan komentar dengan mengklik tombol submit review.

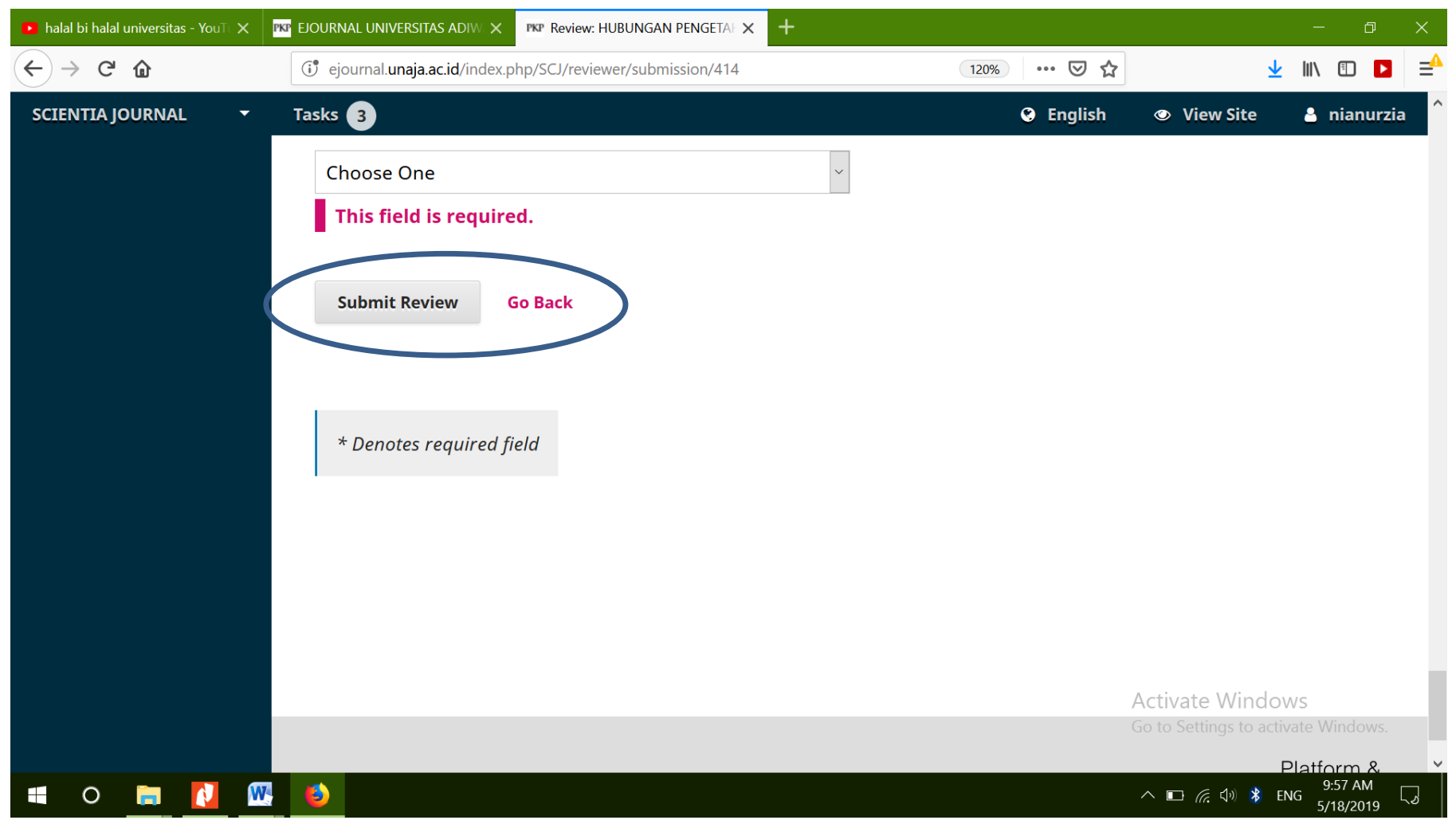


Proses review telah selesai dan akan masuk ke menu completion

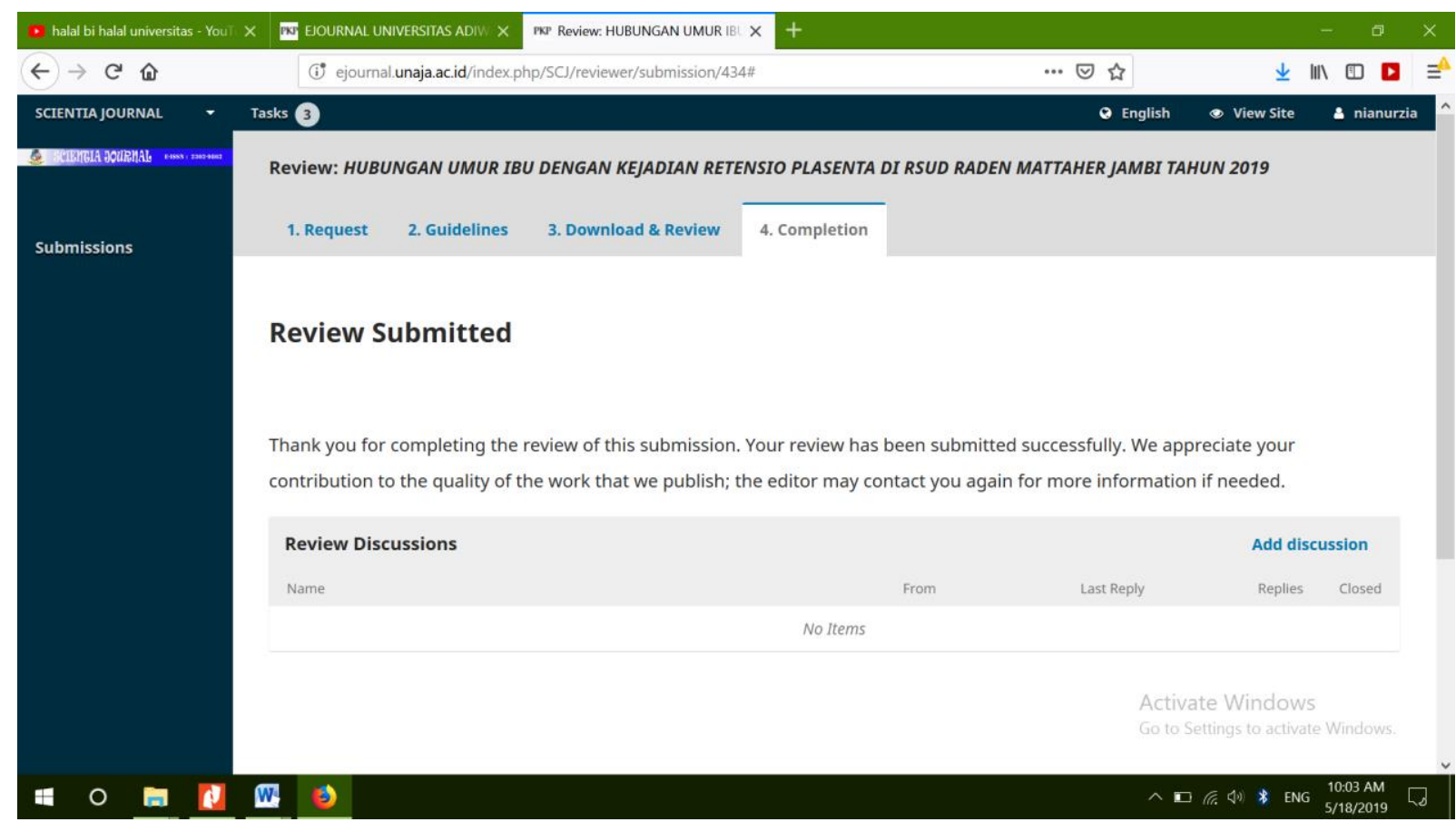

Sampai tahap ini proses review naskah Anda telah selesai dilakukan. Anda dapat berkunjung kembali pada waktu-waktu berikutnya untuk melihat hasil tanggapan naskah Anda dari editor ataupun author.

Aturan/ ketentuan publikasi ilmiah :

1. Artikel yang di submit harus sesuai dengan focus dan scope dari jurnal tersebut kecuali artikel tersebut berisi cakupan keilmuan antar disiplin ilmu.

2. Wajib mengikuti format template yang diberikan.

3. Setiap hasil penelitian mahasiswa DIII, DIV dan S1 wajib untuk disebarluaskan kecuali hasil penelitian yang bersifat rahasia, mengganggu, dan/atau membahayakan kepentingan umum.

4. Setiap hasil penelitian dosen wajib untuk disebarluaskan kecuali hasil penelitian yang bersifat rahasia, mengganggu, dan/atau membahayakan kepentingan umum.

5. Penyebarluasan informasi hasil penelitian adalah merupakan proses pembelajaran dan tanggungjawab akademik oleh peneliti. 
